\title{
Phytochemical Screening and Antimicrobial Activity of Rhizomes of Hedychium spicatum
}

\author{
Ritu Arora*, Avijit Mazumder
}

\section{Ritu Arora*, Avijit Mazum- der}

Pharmacy Institute Noida Institute of Engineering and Technology, 19, Knowledge Park-II, Greater Noida, Uttar Pradesh 201 306.INDIA.

\section{Correspondence}

\section{Ritu Arora}

Pharmacy Institute, Noida Institute of Engineering and Technology, 19, Knowledge Park-II, Greater Noida, Uttar Pradesh 201 306, INDIA.

Phone no: 9910291959

E-mail: ritu.wadhwa84@gmail.com

History

- Submission Date: 17-08-2017;

- Review completed: 11-09-2017;

- Accepted Date: 02-11-2017

\section{DOI : 10.5530/pj.2017.6s.159}

Article Available online

http://www.phcogj.com/v9/i6s

\section{Copyright}

(C) 2017 Phcog.Net. This is an openaccess article distributed under the terms of the Creative Commons Attribution 4.0 International license.

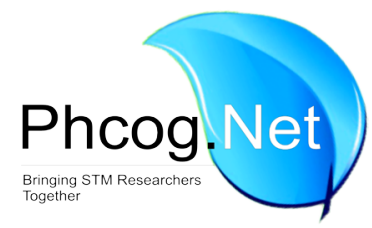

\begin{abstract}
Background: The use of and search for drugs and dietary supplements derived from plants have accelerated in recent years. Objective: In this study the rhizomes of Hedychium spicatum (Zingiberaceae) were evaluated for phytochemical parameters \& antimicrobial activity by determining its MIC (by checker board method) and zone of inhibition (by cup plate method). Phytochemical parameters were studied with the aim of drawing the pharmacopoeial standards for this species. This study was also designed to evaluate the antimicrobial efficacy of the methanolic extract of the rhizomes of $H$. spicatum against various diarrhea and dysentery causing drug resistant microorganisms isolated from patients admitted in hospitals. Methods and Material: The raw materials of $H$. spicatum were procured from the local supplier. Various Microbial strains included various drug resistant hospital isolates collected and characterized in the Dept. of Pharmaceutical Technology, Jadavpur University, India. Results: It was evident from the results that the extract was highly active against Shigella boydii, Shigella. soneii, Shigella flexneri, B. cereus, Vibrio cholera, E. coli, S. aureus, Ps. aeruginosa and K. pneumoniae. The result of determination of zone of inhibition was compared with that of standard drug (Ciprofloxacin). This study has pointed to the potential application of $H$. spicatum as a bactericide and fungicide. Conclusions: The findings of this study further reinforces the importance of $\mathrm{H}$. spicatum rhizomes in traditional healthcare practice and its use in culinary. Further investigation is however needed to isolate and purify the bioactive antimicrobial principles for potential development into generic antimicrobials.

Key words: Bactericide, MIC, Fungicide, Diarrhea. H. spicatum.
\end{abstract}

\section{INTRODUCTION}

H. spicatum (Ham-ex-Smith) is a perennial rhizomatous herb belonging to the family Zingiberaceae. It grows throughout the subtropical Himalaya in the Indian state of Assam, Arunachal Pradesh and Uttarakhand within an altitudinal range of $1000-3000 \mathrm{~m} .{ }^{1,2}$ H. spicatum rhizome is mentioned as Shati in Ayurvedic classics and has been used in various dosage forms to treat cough, wound ulcer, fever, respiratory problems and hiccough. The rhizomes have a strong aromatic odor and bitter taste. In local language, the rhizomes are commonly known as kapur kachari or ban Haldi. ${ }^{3}$ Rhizomes are also used as perfume in tobacco and insect repellent. The rhizome extract has been reported to contain essential oil, starch, resins, organic acids, glycosides, albumen and saccharides, which has been advocated for blood purification and treatments of bronchitis, indigestion, eye disease and inflammations. ${ }^{4,5}$ Rhizome is reported to contain sitosterol and its glucosides, furanoid diterpene-hedychenone and 7-hydroxyhedychenone and essential oil contains cineole, terpinene, limonene, phellandrene, p-cymene, linalool and terpeneol. The plant rhizomes possess hypoglycemic, vasodialator, spasmolytic, hypotensive, antioxidant properties. ${ }^{6}$ Powdered rhizome of $H$. spicatum has been used clinically for the treatment of asthma ${ }^{7}$ and tropical pulmonary eosinophilia ${ }^{8}$ and as antiinflammatory and analgesic. ${ }^{9}$

An extensive search of the literature reveals no reports on the antimicrobial activity of the plant. Thus, present investigation was planned to find out the therapeutic level of methanolic extract of H. spicatum plant in antimicrobial activity.

\section{MATERIALS AND METHODS}

\section{Plant Material}

The raw materials of $\mathrm{H}$. spicatum were procured from the supplier (S.S. Herbal, 485/2, Katra Ishwar Bhavan, Khari Baoli, Delhi) and the sample was identified and authenticated. $100 \mathrm{gm}$ of air dried powdered plant material was extracted with methanol in soxlet apparatus for $96 \mathrm{hrs}$. After that the extract was filtered and again suspended in the above mixture for 24 hrs. Finally extracts was filtered and concentrated over water bath at a temperature of $40^{\circ} \mathrm{C}$. The extract was cooled and kept in desiccator overnight. The extracts was weighed and used for antibacterial and antifungal potentiality. 


\section{Test microorganisms}

The test bacteria used were Shigella flexneri type 36 NK 381, Sh. flexneri type 6B 999, Sh. flexneri type BCH 995, Sh. boydii 22461, Sh. boydii 16552, Sh. boydii 8, Sh. soneii BCH 397, Sh. soneii E08869, Sh. soneii NK 840, Sh. soneii BCH 937, Sh. soneii I, Sh. soneii DN3, Sh. soneii F11001, Sh. soneii NK 29, Sh. dysenteriae 1, Sh. dysenteriae 9, Vibrio cholerae 1023, V. cholerae BD 1/81, V. cholerae 1341, V. cholerae 452, V. cholerae 1033, V. cholerae 575, V. cholerae 765, V. cholerae 1311, V. cholerae 756, V. cholerae DN6, V. cholerae A 26, Escherichia. coli AP600, E. coli 383, E. coli RH 07/12, E. coli 18/9, E. coli 597, E. coli 798, E. coli 35B, E. coli 306, E. coli K88, E. coli 872, Enterobacter spp. AP596, S. typhii Type 2, S. aureus ML 267, Staphylococcus. aureus ATCC 6538, S. aureus MTCC 96, S. aureus 381, Bacillus. subtilis MTCC 441, B. cereus MTCC 1305, B. pumilus 8241, Pseudomonas putida MTCC 2252, P. aeuriginosa AP585 NLF, Klebsiella pneumoniae and Proteus vulgaris AP679 NLF. These microbial strains included various drug resistant hospital isolates collected and characterized in the Department of Pharmaceutical Technology, Jadavpur University, India. All strains were maintained on Nutrient Agar (NA) for bacteria and Sabourauds's Dextrose Agar (SDA) slants for fungi at $4^{\circ} \mathrm{C}$ prior to use for antibacterial and antifungal tests respectively.

\section{Physicochemical Analysis}

All parameters were applied on rhizome physicochemical analysis i.e., percentage of ash values and extractive values, were performed according to the official methods prescribed in Indian Pharmacopoeia, 1996 and the WHO guidelines on quality control methods for medicinal plant materials (WHO/QCMMPM guidelines). ${ }^{10}$

\section{Preliminary Phytochemical Screening}

Chemical tests were performed in the preliminary phytochemical screening to identify various secondary metabolites such as tannins and phenols, carbohydrates, glycosides, saponins, alkaloids, flavonoids and sterols using standard methods. ${ }^{11,12}$

\section{Determination of MIC by Serial Dilution technique}

The rhizome extract (stock solution) was reconstituted with a minimum amount of dimethyl sulfoxide (DMSO). This solvent did not possess any antimicrobial activity of its own. Calculated volumes of this stock solution were dispensed in a series of McCartney bottles previously containing calculated volume of sterile cooled molten nutrient agar media $\left(40-45^{\circ} \mathrm{C}\right)$ to prepare final volume of $30 \mathrm{ml}$ each with dilutions of $5,10,25,50,100,200,400,800$ and $1000 \mu \mathrm{g} / \mathrm{ml}$. The stock solution were dispensed into molten SDA to prepare varying dilutions of 100, 200, 400, 800,1500 and $2000 \mu \mathrm{g} / \mathrm{ml}$ while determining the MIC against the fungi.
Then these molten media containing varying concentration of extract were poured aseptically in pre-sterilized Petri dishes $(70 \mathrm{~mm})$ to give sterile nutrient agar plates with varying dilution of extract. These plates were then kept in refrigerator at $4^{\circ} \mathrm{C}$ for $24 \mathrm{hrs}$ to ensure uniform diffusion of the extract. Then these plates were dried at $37^{\circ} \mathrm{C}$ for bacteria and $25^{\circ} \mathrm{C}$ for fungi for 2 hours before spot inoculations. One loopful (loop diameter: $3 \mathrm{~mm}$ ) of an overnight grown bacterial strain suspension (105 CFU/ml) was added in each quadrant as marked by checker board technique. The spotted plates were incubated at $37^{\circ} \mathrm{C}$ and $25^{\circ} \mathrm{C}$ for 24 hours for bacteria and fungi respectively, in an incubator and MIC values were obtained. ${ }^{13,14,15}$

\section{Determination of Mode of Action of the Extract}

To determine whether the extract was bacteriostatic or fungistatic and bactericidal or fungicidal in nature, plugs from the zone of inhibition were taken out and reincubated into fresh media which were then examined for their growth after 96 hours incubation at $37^{\circ} \mathrm{C}$ and $25^{\circ} \mathrm{C}$ in an incubator, respectively. ${ }^{15,16}$

\section{RESULTS AND DISCUSSION}

\section{Physicochemical Studies}

Ash value of a drug gives an idea of the earthy matter or the inorganic composition and other impurities present along with the drug. Extractive values are primarily useful for the determination of exhausted or adulterated drugs. The alcohol soluble extractive was high in rhizomes of H. spicatum. The results of physicochemical constants of the drug powder are presented in (Table 1).

\section{Preliminary Phytochemical Screening}

Preliminary phytochemical screening of the extract revealed the presence of tannins, saponins, flavonoids, steroids, terpenoids, cardiac glycosides and reducing sugar in it (Table 2).

Table 1: Physicochemical Studies of $\boldsymbol{H}$. spicatum

\begin{tabular}{cc}
\hline Parameter & Result \\
\hline Ash value & $6.9 \%$ \\
Acid insoluble value & $1.03 \% \mathrm{w} / \mathrm{v}$ \\
Water soluble Ash & $2.61 \% \mathrm{w} / \mathrm{v}$ \\
Water insoluble Ash & $2.10 \mathrm{w} / \mathrm{v}$ \\
Moisture content & $5.25 \% \mathrm{w} / \mathrm{w}$ \\
Extractive value(water soluble) & $13.9 \mathrm{w} / \mathrm{v}$ \\
Extractive Value (alcohol soluble) & $5.24 \mathrm{w} / \mathrm{v}$ \\
pH of $1 \%$ suspension & $5.41 \mathrm{w} / \mathrm{v}$ \\
\hline
\end{tabular}

Table 2: Physicochemical Constants

\begin{tabular}{|c|c|c|c|c|c|c|c|}
\hline Phytoconstituents & $\begin{array}{c}\text { Petroleum } \\
\text { Ether }\end{array}$ & Chlorofom & Acetic acid & Acetone & Methanol & Aqueous & Benzene \\
\hline Alkaloids & - & - & + & - & + & + & - \\
\hline Carbohydrate & - & - & + & + & + & + & + \\
\hline Flavonoids & + & - & - & + & + & + & - \\
\hline Gums\& Mucilage & - & - & - & + & - & + & + \\
\hline Glycosides & + & - & - & - & + & + & - \\
\hline Phenolic compounds & - & + & - & + & - & - & - \\
\hline Protein & + & + & - & + & + & + & + \\
\hline Amino acid & - & - & - & + & - & - & + \\
\hline Saponins & + & - & + & + & + & + & - \\
\hline Steroids & + & + & - & - & + & - & - \\
\hline Triterpenes & - & - & - & - & - & - & - \\
\hline Tannins & - & + & - & - & + & + & + \\
\hline
\end{tabular}


Table 3: Determination of MIC of the rhizomes extracts of $\boldsymbol{H}$. spicatum against different bacterial strains:

\begin{tabular}{|c|c|c|c|c|c|c|c|c|c|c|c|}
\hline Name of M/O & 0 & 5 & 10 & 25 & 50 & 100 & 200 & 400 & 600 & 800 & 1000 \\
\hline Shigella flexneri type $36 \mathrm{NK} 381$ & + & + & + & + & + & + & - & - & - & - & - \\
\hline Sh. flexneri type BCH 995 & + & + & + & \pm & - & - & - & - & - & - & - \\
\hline Sh. flexneri type 6 ВСН 999 & + & + & \pm & \pm & - & - & - & - & - & - & - \\
\hline Sh. boydii 22461 & + & + & + & + & + & + & + & + & - & - & - \\
\hline Sh. boydii 16552 & + & + & + & + & + & + & \pm & \pm & \pm & - & - \\
\hline Sh. boydii 8 & + & + & + & \pm & \pm & \pm & \pm & \pm & - & - & - \\
\hline Sh. sonnei BCH 397 & + & + & + & + & + & + & + & - & - & - & - \\
\hline Sh. sonnei E08869 & + & + & + & + & + & + & - & - & - & - & - \\
\hline Sh. sonnei NK 840 & + & + & + & \pm & \pm & \pm & \pm & - & - & - & - \\
\hline Sh. sonnei BCH 937 & + & + & + & + & + & + & \pm & \pm & \pm & \pm & - \\
\hline Sh. sonnei 1 & + & + & + & \pm & \pm & \pm & - & - & - & - & - \\
\hline Sh. sonnei DN3 & + & + & + & + & + & + & + & . & 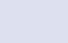 & - & + \\
\hline Sh. sonnei F11001 & + & + & + & + & + & - & - & - & - & - & - \\
\hline Sh. sonnei NK 29 & + & + & + & + & + & + & + & - & - & - & - \\
\hline Sh. dysenteriae 1 & + & + & + & + & + & + & + & \pm & - & - & - \\
\hline Sh. dysenteriae 9 & + & + & + & + & + & + & + & + & + & \pm & \pm \\
\hline Vibrio cholerae 1023 & + & + & + & + & + & + & - & - & - & - & - \\
\hline V. cholerae BD 1/81 & + & + & + & + & \pm & \pm & \pm & - & - & - & - \\
\hline V. cholerae 1341 & + & \pm & \pm & - & - & - & - & - & - & - & - \\
\hline V. cholerae 452 & + & + & + & + & + & + & + & + & + & + & + \\
\hline V. cholerae 1033 & + & + & + & + & + & + & + & + & - & - & - \\
\hline V. cholerae 575 & + & + & + & + & + & + & - & - & - & - & - \\
\hline V. cholerae 765 & + & + & + & + & + & + & + & \pm & - & - & - \\
\hline V. cholerae 1311 & + & + & + & + & + & + & - & - & - & - & - \\
\hline V. cholerae 756 & + & + & + & \pm & \pm & - & - & - & - & - & - \\
\hline V. cholerae DN6 & + & + & + & + & + & + & + & + & + & + & + \\
\hline V. cholerae A 26 & + & + & + & + & + & + & + & + & + & + & + \\
\hline Escherichia coli AP600 & + & + & + & + & + & + & + & + & + & + & + \\
\hline E. coli 383 & + & + & + & + & + & + & + & + & + & + & + \\
\hline E. coli $R H$ 07/12 & + & + & + & + & + & + & + & \pm & - & - & - \\
\hline E. coli $18 / 9$ & + & + & + & - & - & - & - & - & - & - & - \\
\hline E. coli 597 & + & + & + & + & + & \pm & - & - & 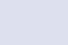 & - & - \\
\hline E. coli 798 & + & + & + & + & + & \pm & - & - & - & - & - \\
\hline E. coli $35 B$ & + & + & + & + & \pm & - & - & - & - & - & - \\
\hline E. coli 306 & + & + & + & + & + & \pm & - & - & - & - & - \\
\hline E. coli $\mathrm{K} 88$ & + & + & + & + & + & + & \pm & \pm & \pm & - & - \\
\hline E. coli 872 & + & + & + & + & + & \pm & - & - & - & - & - \\
\hline Proteus vulgaris AP679 NLF & + & + & + & + & \pm & \pm & - & - & - & - & - \\
\hline Pseudomonas putida MTCC 2252 & + & + & + & + & + & \pm & + & - & - & - & - \\
\hline Ps. aeruginosa AP585 NLF & + & + & + & \pm & \pm & \pm & - & - & - & - & - \\
\hline Enterobacter spp. AP596 & + & + & + & + & + & + & + & + & + & + & + \\
\hline Klebsiella pneumoniae & + & + & + & + & \pm & \pm & \pm & \pm & \pm & - & - \\
\hline Salmonella typhii Type 2 & + & + & \pm & - & - & - & - & - & - & - & - \\
\hline Staphylococcus aureus ML 267 & + & + & + & + & + & + & + & \pm & - & - & - \\
\hline S. aureus ATCC 6538 & + & + & + & \pm & \pm & \pm & \pm & \pm & - & - & - \\
\hline S. aureus MTCC 96 & + & + & + & + & \pm & \pm & - & - & - & - & - \\
\hline S. aureus 381 & + & + & \pm & \pm & - & - & - & - & - & - & - \\
\hline Bacillus subtilis MTCC 441 & + & + & + & + & + & + & \pm & - & - & - & - \\
\hline B. cereus MTCC 1305 & + & + & + & + & + & + & - & - & - & - & - \\
\hline B. pumilus 8241 & + & + & + & + & + & \pm & \pm & \pm & \pm & \pm & - \\
\hline
\end{tabular}


Table 4: Determination of diameter of zone of inhibition (in $\mathrm{mm}$ ) produced by the methanolic extract of the rhizomes of $H$. spicatum and its comparison with that of Ciprofloxacin against selected sensitive bacterial strains*

\begin{tabular}{|c|c|c|c|c|c|c|c|c|c|c|}
\hline \multirow[t]{2}{*}{ NAME OF BACTERIA } & \multicolumn{5}{|c|}{$\begin{array}{c}\text { ZONE OF INHIBITION PRODUCED BY EXTRACT OF } \\
\text { H. spicatum }\end{array}$} & \multicolumn{5}{|c|}{ ZONE OF INHIBITION PRODUCED BY Ciprofloxacin } \\
\hline & $\begin{array}{c}200 \\
\mu \mathrm{g} / \mathrm{ml}\end{array}$ & $\begin{array}{c}400 \\
\mu \mathrm{g} / \mathrm{ml}\end{array}$ & $\begin{array}{c}800 \\
\mu \mathrm{g} / \mathrm{ml}\end{array}$ & $\begin{array}{c}1000 \\
\mu \mathrm{g} / \mathrm{ml}\end{array}$ & $\begin{array}{c}1200 \\
\mu \mathrm{g} / \mathrm{ml}\end{array}$ & $\begin{array}{c}200 \\
\mu \mathrm{g} / \mathrm{ml}\end{array}$ & $\begin{array}{c}400 \\
\mu \mathrm{g} / \mathrm{ml}\end{array}$ & $\begin{array}{c}800 \\
\mu \mathrm{g} / \mathrm{ml}\end{array}$ & $\begin{array}{c}1000 \\
\mu \mathrm{g} / \mathrm{ml}\end{array}$ & $\begin{array}{l}1200 \\
\mu \mathrm{g} / \mathrm{ml}\end{array}$ \\
\hline Pseudomonas putida MTCC 2252 & 6.5 & 9.0 & 11.5 & 15.0 & 17.5 & 10 & 12 & 14 & 18 & 20 \\
\hline Ps. aeruginosa AP585 NLF & 6.5 & 7.0 & 7.5 & 8.0 & 8.5 & 11.5 & 12.5 & 14 & 16 & 18 \\
\hline V. cholera 1023 & 5.5 & 6.5 & 8.5 & 9 & 15 & 12 & 21 & 24 & 28 & 30 \\
\hline V. cholera 1341 & 4.5 & 6.5 & 7 & 11 & 18 & 11 & 19 & 21 & 27 & 29 \\
\hline V. cholerae 1311 & 6.0 & 7.7 & 8 & 10.5 & 16 & 12 & 18 & 22 & 26 & 28 \\
\hline V. cholerae 575 & 4 & 5 & 6 & 9 & 15 & 10 & 15 & 21 & 30 & 32 \\
\hline V. cholerae 756 & 9.0 & 11.5 & 13.5 & 14.5 & 16 & 9 & 9.5 & 11 & 13 & 16 \\
\hline E. coli $18 / 9$ & 8.4 & 9.0 & 9.5 & 10.0 & 10.5 & 11.5 & 12.0 & 12.5 & 13.0 & 13.5 \\
\hline E. coli 798 & 8.5 & 9.0 & 10.0 & 11.5 & 12.5 & 11.5 & 12.5 & 13.0 & 13.5 & 14.5 \\
\hline E. coli 872 & 6.5 & 6.5 & 8.0 & 10.0 & 13.5 & 11 & 17 & 21 & 28 & 29 \\
\hline E. coli 358 & 6.5 & 8.0 & 9.5 & 13.0 & 18.5 & 11 & 20 & 24 & 26 & 28 \\
\hline Enterobacter spp. AP596 & 7.0 & 7.5 & 9.5 & 10.5 & 11.0 & 9.0 & 9.5 & 11.5 & 12.0 & 13.5 \\
\hline Proteus vulgaris AP679 NLF & 7.5 & 8.5 & 10.0 & 11.5 & 12.0 & 10 & 13 & 15 & 16.5 & 18.0 \\
\hline Salmonella typhii Type 2 & 8.0 & 8.5 & 10.0 & 10.5 & 11.0 & 11.5 & 12.0 & 13.5 & 14.5 & 15 \\
\hline Bacillus subtilis MTCC 441 & 6.0 & 7.5 & 8.0 & 9.0 & 10 & 11 & 12.5 & 13.5 & 14.5 & 16 \\
\hline B. subtilis MTCC441 & 8.0 & 8.5 & 11.5 & 14.5 & 18.5 & 10 & 18 & 20 & 27 & 32 \\
\hline Staphylococcus aureus 381 & 7.5 & 9.0 & 11.0 & 12.5 & 13.0 & 9.5 & 11.0 & 12.5 & 14.0 & 14.5 \\
\hline Shigella flexneri type 36 NK 381 & 6.5 & 7.0 & 7.5 & 8.5 & 9.0 & 10.0 & 10.5 & 11.0 & 11.5 & 12.5 \\
\hline Sh.soneii F11001 & 9.5 & 10.2 & 11.8 & 13.5 . & 15.0 & 17 & 25 & 29 & 34 & 31 \\
\hline Sh. flexneri type BCH 995 & 9.5 & 10.5 & 12.0 & 13.0 & 13.8 & 12.0 & 12.5 & 13.4 & 14.0 & 14.7 \\
\hline
\end{tabular}

${ }^{*}$ Average of two plates)

\section{Antibacterial Activity}

The result in Table 3 depicted the MIC values of the methanolic extract of the rhizomes of $H$. spicatum against various tested bacterial pathogens.

It was evident from the results shown in the Table 3 that the extract was highly active against Shigella boydii, Sh. soneii, Shigella flexneri, B. cereus, Vibrio cholera, E. coli, S. aureus, Ps. aeruginosa and K. pneumoniae. The result of determination of zone of inhibition of the crude extract of the rhizomes of the plant and their comparison with those of standard antibacterial agent Ciprofloxacin against the tested bacterial strains is recorded in Table 4.

The sensitivity pattern of the bacterial organisms to the extract was found to decrease in the following order: E. coli 358, B. subtilis MTCC441, V. cholera 1341, Pseudomonas putida MTCC 2252, V. cholerae 1311, V. cholerae 756, V. cholerae 575, V. cholera 1023, E. coli 872, E. coli 798, E. coli 18/9, Ps. aeruginosa AP585 NLF, as evident from table 5.

\section{CONCLUSION}

The pharmacognostical and phytochemical evaluation of H. spicatum (Zingiberaceae)) rhizome provided useful information for identification and authentication of the plant. The antibacterial study of the methanolic extract of the rhizomes of $H$. spicatum showed the maximum activity against Shigella boydii, Sh. soneii, Shigella flexneri, B. cereus, Vibrio cholera, E. coli, S. aureus, Ps. aeruginosa and K. pneumoniae. The results of phytochemical analysis and antimicrobial activity studies of the plants extracts confirmed its therapeutic usage, as depicted in the literature.
The active plant extract may be further subjected to biological and pharmacological investigations for isolation of antibacterial and therapeutic compounds.

\section{ACKNOWLEDGEMENT}

The authors are grateful to extend special thanks to Dr. G. S. Chakraborthy, Pharmacy Institute Noida Institute of Engineering and Technology, Greater Noida, for his constant encouragement \& support throughout the work.

\section{CONFLICTING INTEREST}

The authors are declared no conflict of interest.

\section{ABBREVIATION USED}

H. spicatum: Hedychium spicatum; (B.): Bacillus; (S.): Staphylococcus; (P.): Pseudomonas; (E.): Escherichia; (V.); Vibrio.

\section{REFERENCES}

1. Samant SS, Dhar U. Diversity, endemism and economic potential of wild edible plants of Indian Himalaya. Int J Sust Dev World 1997;4(1):79-91.

2. Thakur RS, Puri HS, Hussain A. Major medicinal plants of India. CIMAP Publication, Lucknow; 1989. p. 50-2

3. Chopra RN, Nayar SL, Chopra LC. Glossary of Indian medicinal plants, New Delhi: CSIR Publication; 1956. p.13-131.

4. Srimal RC, Sharma SC, Tandon JS. Anti-inflammatory and other pharmacological effects of Hedychium spicatum (Buch-Hem). Indian J Pharmacol $1984 ; 16(3): 143-7$ 
5. Sravani T, Paarakh MP. Hedychium spicatum Buch. Ham.-An overview. Pharmacologyonline $2011 ; 2: 633-42$.

6. Giri D, Tamta S, Pandey A. A review account on medicinal value of Hedychium spicatum Buch-Ham ex Sm. Vulnerable medicinal plant. J. Med. Plants Res 2010; 4: 2773-7.

7. Chaturvedi GN, Sharma BD. Clinical studies on Hedychium spicatum (Shati): An antiasthmatic drug. J res indian med. 1975;10(2):941.

8. Sahu RB. Clinical trial of Hedychium spicatum in tropical pulmonary eosinophilia. Journal of Nepal Pharmaceutical Association, 1979;7:65-72.

9. Tandon SK, Chandra S, Gupta S, J. Lal: Analgesic and anti-inflammatory effects of Hedychium spicatum. Indian J. Pharm. Sci 1997;59(3):148-50.

10. WHO/QCMMPM. Quality Control Methods for Medicinal Plant Material, Organ- isation Mondiale De La Sante, Geneva; 1992. p.22-34.

11. Khandelwal KR. Practical Pharmacognosy. 7th Ed. CBS publishers and distributors, 2004;149-56.

12. Kokate CK. Practical Pharmacognosy, $4^{\text {th }}$ Ed. Vol. I, Vallabh Prakashan; 2005.p. 16.

13. Mazumder R, Mendiratta T, Mandal SC, Mazumder A. Antimicrobial potency of the leaf stalk extract of Curcuma longa Roxb. Anc Sci Life 2000;(1-2): 92-6.

14. Mazumder A, Singh SK, Mazumder R, Basu SP, Saha BP. Antimicrobial action of the leaf extract of Lagerstroemia parviflora Roxb. Anc Sci Life 2001; XXI (3):198-201.

15. Karuba RM, Siboe GM and Dossaji SF. Antifungal activity of Schizozygia coffaeoids Bail. (Apocynaceae) extract. J Ethnopharmacol 2001;74(1):41-4.

\section{GRAPHICAL ABSTRACT}

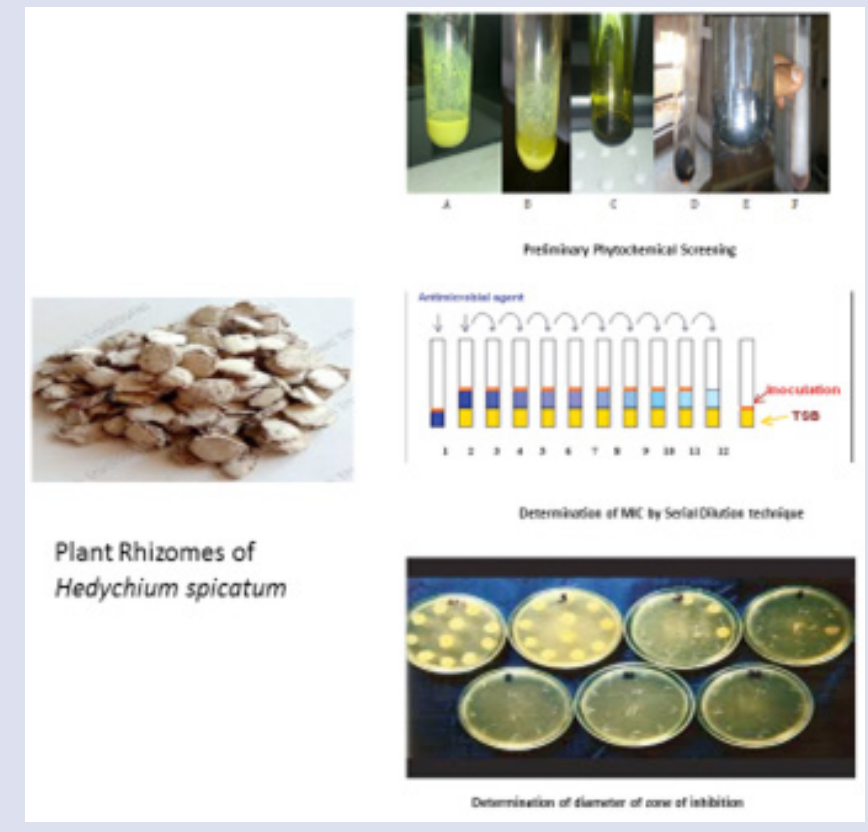

\section{SUMMARY}

- Hedychium spicatum is a good source for flavonoid compounds.

- Methanolic extract had shown strong positivity in preliminary phytochemical screening.

- Antimicrobial activity performed by determining its MIC (by checker board method) and zone of inhibition (by cup plate method)

- Antibacterial study of the methanolic extract of the rhizomes of $\mathrm{H}$. spicatum showed the maximum activity against Shigella boydii, Sh. soneii, Shigella flexneri, B. cereus, Vibrio cholera, E. coli, S. aureus, Ps. aeruginosa and K. pneumoniae.

\section{ABOUT AUTHORS}

Ritu Arora: Is a Research Scholar at Dr. Abdul Kalam University, Lucknow. Her research is focused on Phytochemical analysis of plants and herbal products, pharmacological screening of plant and plant products.

Dr Avijit Mazumder: Is working as Professor and Director in the NIET Pharmacy Institute in Noida Institute of Engineering and Technology since October 2009. He had a total of more than one hundred eighty national and international publications to his credit. He had contributed eight book chapters and is the author of three books of repute.

Cite this article: Arora R, Mazumder A. Phytochemical Screening and antimicrobial activity of rhizomes of Hedychium spicatum. Pharmacog J. 2017;9(6)Suppl:s64-s8. 